\title{
The Determination of Product Distribution Route based on Nearest Neighbour and Genetic Algorithm
}

\author{
Y Erdhianto ${ }^{1}$, Suhartini $^{1}$, Sutrisno ${ }^{1}$ and R Mitrasari ${ }^{1}$ \\ ${ }^{1}$ Department of Industrial Engineering, Faculty of Industrial Engineering \\ yoniv@itats.ac.id
}

\begin{abstract}
One of logistics activities is product distribution. PT Stars has several obstacles in their distribution activity including the limited number and capacity of the company vehicles, the difference in the number of consumer requests, and the spread consumer locations. The methods used in this research were Saving Matrix, Nearest Neighbor, and Genetic Algorithm. By employing biological evolution concept, an output was produced in the form of a combination of goods distribution route that should be taken to optimize the capacity and travel cost. The results obtained from the calculation on Saving Matrix and Nearest Neighbor were two routes for Genetic Algorithm manually and constructively using MATLAB at PT Stars Internasional. Based on the calculation process, two solutions were obtained using Nearest Neighbor with two distribution routes, while 14 distribution routes were generated using Genetic Algorithm with a maximum capacity of 3,720 pairs.
\end{abstract}

\section{Introduction}

In the industrial world, the system of scheduling and managing distribution route has an important role for the company. A company both manufacturing and service realize that logistics has a very important role in costs, decisions regarding logistics, and the determination of logistics distribution routes.

Planning in the use of transportation for product delivery considers the number of goods and time of delivery. By doing distribution planning, it is expected to increase profit since the total transportation cost can be minimized without neglecting market demand so that it can meet market needs.

According to Ronald H. Ballou [1], routing problems may improve product distribution routes, so as to provide input on the process of delivery, scheduling, and logistics management on the available vehicles. To achieve efficient result and absolute effectiveness, a good organization is needed. Logistics management will result in a right number of goods or service as well as right place and time at the desired target with major contribution to the company [1].

One of the most important decisions in distribution management is determining the schedule and delivery route from one point to several destination points. PT Stars International is one of manufacturing companies engaged in shoes and sandals production in Surabaya. The products produced by this company are sold in big cities all over Java island. The work system in PT Stars International is based on job order and job stock in which the distribution process is carried out after the consumers placed their orders. The selling system is done in cash only. This company always pays attention to and prioritizes customer requests by sending ordered goods in accordance with the agreement. In addition, the company also guarantees customers the quality of their products and 


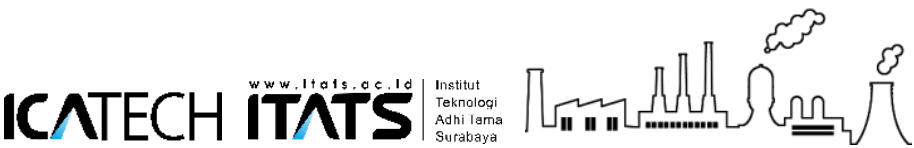

provides low prices to customers. In terms of distribution, the company has sixteen cities in East Java as places to market their products.

Problems faced by PT Stars Internasional are high cost of distribution and ineffective routes to arrive at the selling stores. Although the sales have almost spread throughout Indonesia, the product warehouses which are still in Surabaya cause the delays in delivery to areas far from reach. From those problems, the company needs to optimize its distribution system to help them in competing with other companies. Therefore, by planning the distribution expenditure, there will be an increase in profits because the total transportation costs can be minimized without neglecting the market demands. In addition, it is important to pay attention to which level of market demands that will be fulfilled first with a route that meets the request.

These problems are solved by using Genetic Algorithm with the aim of proposing product distribution routes to the company to optimize distribution cost. Genetic Algorithm is an algorithm which applies an understanding of natural evolution aiming to solve problems. The algorithm approach aims to randomly combine the best choice of solutions in a group to get the best generation of solution. This generation will represent improvements in the original population. By doing this process repeatedly, this algorithm is expected to stimulate an evolutionary process.

By employing biological evolution concept, an output will be produced in the form of a combination of goods distribution route that should be taken to optimize the capacity and travel cost. Each solution obtained should be re-evaluated which causes longer time taken for using Genetic Algorithm compared to using other methods (Derivintri, 2015). According to Novita (2014), Genetic Algorithm is used to complete optimization in various fields such as nurse scheduling, jobshop scheduling, water network, as well as transportation problem (distribution). Saving in distribution costs will reduce the cost of goods sold resulting in the increase of company profits.

\section{Literature Review}

\subsection{Definition of Distribution}

According to Chopra and Meindl (2015), distribution is an activity to move goods from supplier to the agents in a supply chain. Distribution is a key to the profits obtained bt the company since the distribution will directly affect the cost of supply chain and agents needs. Nyoman (2014) stated that transportation and distribution management is the management of activities related to the product movement from one point to another in which usually forming a network. In most products, the role of distribution and transportation network is vital. This distribution and transportation network allow products to move from production or consumer locations which are often too far away.

\subsection{Distribution and Transportation Management}

According to Pujawan (2013) distribution and transportation activity can be done by manufacturing company by forming a separate distribution and transportation division or by handing the process over to third parties. In its efforts to fulfill aforementioned objectives, whoever carrying out distribution and transportation management, they generally perform a number of basic functions which consists of: segmenting and determining target service level, determining transportation mode to be used, consolidating information and delivery, scheduling and determining delivery routes, providing added value services, storing inventory, handling return.

\subsection{Genetic Algorithm Basic Theory}

Genetic Algorithm was first developed by Holland (2015) by saying that every problem in the form of adaptation can be formulated in terms of genetics. Genetic Algorithm is a simulation of Darwin's evolution process and genetic operation of chromosomes. 


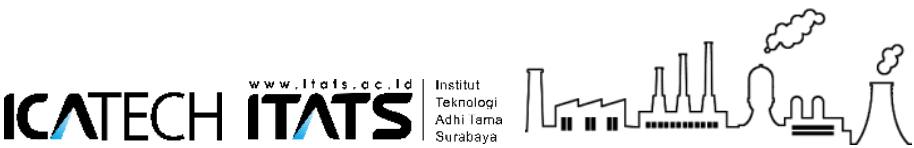

The $1^{\text {st }}$ International Conference on Advanced Engineering and Technology - 2018

\section{Method}

The methods used were Nearest Neighbor and Genetic Algorithm. While the data needed in this study was the data on city names and distance between cities of distribution, type of vehicle used, and fuel costs in one-way distribution. The distribution destinations included Kediri, Jombang, Nganjuk, Magetan, Madiun, Trenggalek, Pacitan, Bondowoso, Tulunggagung, Malang, Jember, Tuban, Bojonegoro, and Lamongan. The data on cost included one-way cost in distributing goods in accordance with the demand.

\section{Analysis And Discussion}

\subsection{The first step was to calculate the distance savings as follows}

The distance savings is calculated by the formula: $\mathrm{S}(\mathrm{x}, \mathrm{y})=\mathrm{J}(\mathrm{P}, \mathrm{x})+\mathrm{J}(\mathrm{P}, \mathrm{y})-\mathrm{J}(\mathrm{x}, \mathrm{y}), \mathrm{S}(1,2)=\quad(22)$ $+(45)-(36)=31 \mathrm{~km}, \mathrm{~J}=$ Distance, $\mathrm{P}=$ Factory, $\mathrm{x}$ and $\mathrm{y}=$ shop $\mathrm{x}$ and shop $\mathrm{y}, \mathrm{S}(\mathrm{x}, \mathrm{y})=$ distance saving was obtained by combining route $x$ and route $y$. PT Stars Internasional used an L 300 with a capacity of four tons in each delivery. By using Nearest Neighbor, two routes were generated in which the first route covered Factory -Malang -Bondowoso - Jember-Tulungagung -Nganjuk -Kediri Madiun - Trenggalek - Pacitan - Magetan - Bojonegoro - Tuban-Lamongan - Factory with a distance of $1,377 \mathrm{~km}$ with transport capacity of 3,270 pairs obtained from $210+310+350+240+$ $220+220+230+220+210+330+220+240+270$. While the second route covered Factory Sidoarjo - Mojokerto -Jombang -Factory with a distance of $154 \mathrm{~km}$ and transport capacity of 830 pairs as a result from $320+270+240$.

Table 1. Proposed Route using Nearest Neighbor

\begin{tabular}{ccccc}
\hline No. & Proposed Route & $\begin{array}{c}\text { Capacity } \\
\text { (Pairs) }\end{array}$ & $\begin{array}{c}\text { Cost } \\
(\mathrm{Rp})\end{array}$ & $\begin{array}{c}\text { Distanc } \\
\mathrm{e} \\
(\mathrm{Km})\end{array}$ \\
\hline 1 & $\begin{array}{c}\text { Factory - Malang - Bondowoso - Jember - } \\
\text { Tulungagung - Nganjuk - Kediri - Madiun - } \\
\text { Trenggalek - Pacitan - Magetan - Bojonegoro - } \\
\text { Tuban - Lamongan - Factory }\end{array}$ & 3.270 & 2.285 .570 & 1.377 \\
\hline \multirow{2}{*}{$\begin{array}{c}\text { Factory - Sidoarjo - Mojokerto - } \\
\text { Jombang -Factory }\end{array}$} & 830 & 832.240 & 154 \\
\hline
\end{tabular}

After knowing the value of Nearest Neighbor method, the distribution route with Genetic Algorithm was determined by taking the following steps: By initialization, a generation with six populations will be generated, then the chromosome was determined to get the fitness scores from six populations, furthermore chromosome evaluation was carried out to get the total fitness value of 0.015234 which was then continued by Crossover process and lastly, in mutation process the smallest fitness value was got which was 361 in the fourth chromosome. Data modelling input, to determine cost and product allocation by considering delivery distance, the data on the relationship between delivery cost needed and delivery distance. The curve which states the relationship between delivery cost and delivery distance is called Cost of Delivery Performance Curve (CDPC). To get an exponential function that can represent the function of the cost curve, data plotting using Matlab R20 software was done. From the result of each data plotting of cost and distance, the coefficients from exponential function were generated. Data plotting from Matlab was used since it provided a good solution which can be observed from the value of Sum Square Error generated and R-square value closing to 1 . 


\section{ICATECH ITATS = =}

The $1^{\text {st }}$ International Conference on Advanced Engineering and Technology - 2018

Table 2. The Result of Particle Swarm Optimization (PSO)

\begin{tabular}{|c|c|c|c|c|c|}
\hline \multicolumn{2}{|c|}{$\begin{array}{c}\text { Initial Population }(\mathrm{N}) 20 \\
\text { and iteration } 100\end{array}$} & \multicolumn{2}{|c|}{$\begin{array}{c}\text { Initial Population (N) } 30 \\
\text { and iteration } 300\end{array}$} & \multicolumn{2}{|c|}{$\begin{array}{l}\text { Initial Population(N) } 40 \\
\text { and iteration } 500\end{array}$} \\
\hline $\mathrm{X}_{\mathrm{Opt}}$ & $F_{\max }$ & $\mathrm{X}_{\mathrm{Opt}}$ & $F_{\max }$ & $\mathrm{X}_{\mathrm{Opt}}$ & $F_{\max }$ \\
\hline $0.262 \mathrm{e}+04$ & & $0.245 e+04$ & & $0.392 e+04$ & \\
\hline $0.330 \mathrm{e}+04$ & & $0.253 e+04$ & & $0.265 e+04$ & \\
\hline $0.316 e+04$ & & $0.261 e+04$ & & $0.359 e+04$ & \\
\hline $0.220 \mathrm{e}+04$ & & $0.329 e+04$ & & $0.370 \mathrm{e}+04$ & \\
\hline $0.347 e+04$ & & $0.356 e+04$ & & $0.270 \mathrm{e}+04$ & \\
\hline $0.321 e+04$ & & $0.373 e+04$ & & $0.352 \mathrm{e}+04$ & \\
\hline $0.250 \mathrm{e}+04$ & & $0.346 e+04$ & & $0.266 e+04$ & \\
\hline $0.260 \mathrm{e}+04$ & & $0.247 e+04$ & & $0.312 \mathrm{e}+04$ & \\
\hline $0.242 \mathrm{e}+04$ & & $0.296 e+04$ & & $0.371 \mathrm{e}+04$ & \\
\hline $0.316 e+04$ & $2.813 e+06$ & $0.291 \mathrm{e}+04$ & $2.672 e+06$ & $0.365 \mathrm{e}+04$ & $2.783 e+06$ \\
\hline $0.327 e+04$ & & $0.289 e+04$ & & $0.273 e+04$ & \\
\hline $0.225 e+04$ & & $0.302 \mathrm{e}+04$ & & $0.336 e+04$ & \\
\hline $0.250 \mathrm{e}+04$ & & $0.346 e+04$ & & $0.317 e+04$ & \\
\hline $0.264 \mathrm{e}+04$ & & $0.274 e+04$ & & $0.365 \mathrm{e}+04$ & \\
\hline
\end{tabular}

The amount of delivery cost prior to optimization was comparable to the average initial capacity shipped between 2,820 - 3,000 pairs. After optimization using PSO method, the amount of delivery cost showed significant result. With PSO method, delivery cost of Rp. 2,783,000 was able to deliver a maximum delivery capacity of 392 pairs or an increase of 23.5 compared to before optimization.

Table 3. The Route Result of Particle Swarm Optimization (PSO)

\begin{tabular}{|c|c|c|c|}
\hline No. & Route Using Genetic Algorithm Matlab Software & $\begin{array}{c}\text { Maximum } \\
\text { Capacity } \\
\text { (Pairs) }\end{array}$ & $\begin{array}{l}\text { Cost Rp } \\
\text { (Million) }\end{array}$ \\
\hline 1. & 0-A01-A10-A12-A03-A08-A07-A05-A04-A15-A14-0 & 2,450 & $2,510,000$ \\
\hline 2. & 0-A01-A10-A13-A12-A03-A08-A07-A05-A04-A15-A13-0 & 2,530 & $2,675,000$ \\
\hline 3. & 0-A01-A013-A03-A11-A14-A07-A05-A02-A13-0 & 2,610 & $2,610,000$ \\
\hline 4 & $\begin{array}{l}\text { 0-A01-A012-A03-A08-A14-A07-A06-A05-A04-A02-A15- } \\
\text { A14A16 }\end{array}$ & 3,290 & $2,730,000$ \\
\hline 5 & $\begin{array}{l}\text { 0-A02-A10-A13-A03-A11-A08-A07-A06-A05-A04-A02- } \\
\text { A15-A14-0 }\end{array}$ & 3,560 & $2,715,000$ \\
\hline 6 & 0-A02-A10-A13-A12-A11-A08-A14-A06-A15-A16-A14-0 & 3,739 & $2,672,000$ \\
\hline 7 & $\begin{array}{l}\text { 0-A01-A10-A13-A03-A08-A07-A05-A04-A02-A15-A16- } \\
\text { A14-0 }\end{array}$ & 3,459 & $2,800,000$ \\
\hline 8 & 0-A01-A10-A12-A04-A11-A14-A06-A04-A02-A16-0 & 2,469 & $2,765,000$ \\
\hline 9 & 0-A01-A12-A11-A08-A07-A06-A06-A05-A04-A15-0 & 2,960 & $2,775,000$ \\
\hline 10 & 0-A01-A10-A13-A12-A03-A08-A09-A07-A04-A02-0 & 2,910 & $2,690,000$ \\
\hline 11 & 0-A01-A12-A11-A08-A09-A07-A06-A05-A04-A12-0 & 2,888 & $2,683,000$ \\
\hline 12 & 0-A01-A10-A13-A12-A03-A11-A08-A09-A06-A05-A16-0 & 3,020 & $2,745,000$ \\
\hline 13. & 0-A01-A13-A12-A09-A03-A11-A08-A09-A06-A05-A16-0 & 3,460 & $2,780,000$ \\
\hline 14 & 0-A01-A13-A12-A11-A09-A07-A02-0 & 2,739 & $2,525,000$ \\
\hline
\end{tabular}




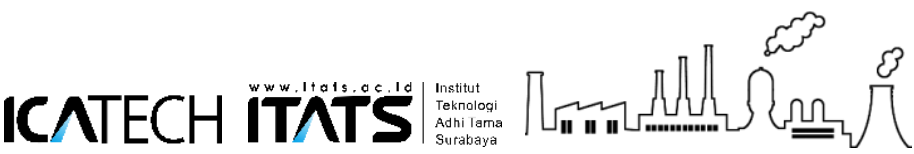

The $1^{\text {st }}$ International Conference on Advanced Engineering and Technology - 2018

The research showed that there was a correlation between the values obtained from optimization results using Particle Swarm Optimization (PSO) through software simulation on the delivery capacity and delivery cost in the field. The calculation was done by correlating between each value of delivery capacity and cost from optimization results on the actual delivery cost. This was done by looking for correlation coefficients between variables in which the maximum correlation value is 1 which indicates that variables have a very high correlation.

\section{Conclusion}

Using the Nearest Neighbor Method, there were two distribution routes in which the first route had a maximum capacity of 3,270 pairs with delivery cost of Rp. 2,285,570 and the second route with a maximum of 830 pairs with delivery cost of Rp. 78,820. Using Genetic Algorithm, one delivery could reach fourteen delivery routes with a maximum capacity of 3,730 pairs with maximum cost of Rp. $2,672,000$. The amount of delivery cost prior to optimization was Rp. 3,000,000 with delivery capacity of 2,820 - 3,000 pairs. After optimization using PSO method, the amount of delivery cost showed significant result. With PSO method, delivery cost of Rp. 2,672,000 was able to deliver a maximum delivery capacity of 3,739 pairs or an increase of 23.5 compared to before optimization.

\section{References}

[1] R. Bollou, Busines Logistics Management. New Jersey: Prentice Hal, Inc, 2013. 